\title{
FACTORS AFFECTING EMPLOYEE ATTRITION AMONG ENGINEERS AND NON-ENGINEERS IN MANUFACTURING INDUSTRY
}

\author{
Dr. Shikha Bhardwaj*1, Mr. Ashutosh Singh² \\ ${ }^{1}$ Assistant Professor, Army Institute of Management \& Technology, Plot No M-1, Pocket P-5, Greater \\ Noida, India, shikhabhardwaj@aimt.ac.in, 9811210611 \\ ${ }^{2}$ HR Executive, TAG Team, IRIS Ltd., Plot No. 25, Sector 142, Noida, India
}

\begin{abstract}
Almost every industry nowadays is badly affected by attrition. Retention of talented employees is the biggest problem faced by India Incorporation. In order to gather more insights on the talent crunch, the undertaken study was conducted on technical and non-technical jobs in manufacturing sector in Delhi NCR. Research has identified three major factors - Salary, Boss and Stress in the jobs after conducted interviews with around 50 technical and non-technical respondents. A set of questions were prepared and send to 120 employee but only 75 responded. The study shows a strong relationship between type of job and factors of attrition. Chi-square test clearly states strong relationship among two. Thus, any change in one will affect the other also. At the same time other important outcomes were that for technical jobs salary is the most important factor whereas non-technical Boss is the factor. Out 75, 63 were engineer and rest were non-engineer. The research can be further done to understand factors of attrition with other demographic variable.
\end{abstract}

\section{Keywords}

Attrition, retention, salary

\section{JEL Classification}

$\mathrm{J} 17, \mathrm{~J} 13$ and J33

DOI: https://doi.org/10.14311/bit.2017.02.04

Editorial information: journal Business \& IT, ISSN 2570-7434, CreativeCommons license (c) (1) published by CTU in Prague, 2017, http://bit.fsv.cvut.cz/ 


\section{Introduction}

The word attrition refers to the process of reducing something's strength or effectiveness through sustained attack or pressure. Attrition, in an organization, refers to reduction or decrease in the size or strength of the work force, or a gradual reduction in labor occurring through various means other than firing employees. The attrition rate plays a significant role in an organization. High attrition rate of employees in an organization is a serious concern because the employees are the backbone of any organization and irreplaceable. No organization can exist without it. But mere existence is not a great deal in fact survival is the main battle. Organization succeeding in retaining talent survives sustainably.

An organization with perfect alignment between employees and employers interest, where no employees leave voluntary or involuntary, is practically impossible. No organization is perfect nor can attrition be cured fully. It can only be reduced to its minimal through practicing best retention strategies. The rate of shrinkage in size or number of employees is known as attrition rate. Different organizations use different method to calculate the rate of attrition. The most common formula to calculate the rate of attrition used by many organizations is:

Attrition Rate $=$ (Number of employees who left in the year / Average employees in the year) $* 100$

Attrition if a part of strategic business manoeuvre to reduce costs can be encouraged. It can also manifest itself when employees voluntarily leave their jobs. Few reasons can be: employees may move or retire, take another job, be ill-suited to the position they were hired to fill, or want employment that offers a more equitable work-life balance. Others may experience a lack of the freedom or autonomy they require to perform at expected levels or facing compensation related problems. Distrust between employee-employers also aids attrition. Human resources professionals unconsciously encourage attrition when they overlook or ignore mistreatment of employees by management.

\section{Positive side of attrition}

Some business strategies use attrition as a part of restructuring plan. Rather than carrying out traditional layoffs, some businesses choose to reduce their workforce through the more gradual means of attrition. This is less consequential to a workforce that contains employees approaching retirement age. When they leave the company, a replacement is not hired to fill the vacancy, and the job position may be retired. Some business houses workout with their HR professionals to create equitable positions into which remaining employees can potentially be promoted. This creates positive employment option which otherwise did not previously exist.

\section{Negative side of attrition}

Due to high attrition rate, cost of the organization increases due to training, development, socialization and other costs on the employees. BPO, paramedical, aeronautics, etc. are few organizations, whose work is mostly dependent on knowledge workers, where attrition rate is basically high. When attrition occurs, the remaining duties and responsibilities can burden employees and managers with additional duties with no increase in pay. This may cause even present managers or employees to move to other companies. The potential for employment promotion may no longer exist when positions are retired due to attrition. Employee morale can suffer. 


\section{Attrition trend in manufacturing sector in India}

With the government's 'Make in India' push and new project launches, the manufacturing sector is likely to face an attrition rate of 8-10 per cent, revealed the survey (Source: The Economic Times). India Inc. is likely to witness attrition rates of up to 25 per cent in 2016, thanks to an upbeat job market and improved economy. Fresher-level attrition is expected to be around 12-14 per cent while at senior-level it will be in the range of 8-10 per cent, according to a survey by job portal (Source: Wisdom Jobs). "The survey reinforces the gut-feel in the recruitment industry that 2016 will see huge employee turnover in most sectors. This churn can primarily be attributed to job seeker optimism arising from a stable economy leading to a spurt in opportunities," said Wisdomjobs.com Founder and CEO Ajay Kolla. Mid and lateral-level attrition is pegged to grow to 15-20 per cent and key role attrition is expected to touch 7 per cent during the year.

Organizations attribute Better Career Prospects, Personal Reasons and Better Utilization of Current Skills as the main reasons for attrition. Career Management, Attraction and Developing Potential Leaders are the key HR challenges faced by this sector. To keep employee motivation and engagement at the highest level of minimize attrition is a challenge for HR professionals in every sector (Source: NDTV Profit).

\section{Literature Review}

The researches reveal that turnover intention has influence on attrition factors such as QWL, career growth, working hours, personal/family reasons, and relation with internal co - worker, welfare, working condition, and salary. There is significant difference between the turnover intention and attrition factor (Lavanya, L, 2013). There is also a positive correlation between high involvement work practices and employee retention and firm productivity. It means that employees give more importance to the quality of job and employer's treatment than salary. Researches reflect a deep sense of understanding and analysis to be carried out among organization when attrition in high. Every organization also needs to be alert all the time and understand the status of the hygiene and motivation factors in their organization by conducting regular satisfaction surveys. The supervisors need to understand the internal and external factors through the lens of hygiene-motivation factor theory. Rate of attrition of employees is dependent on income and working life in the organization (Mishra S \& Mishra D, 2013). The other study shows that to analyze and decide the priority factors, which cause the attrition in the rapid growing Indian manufacturing sector are: a. Monetary Benefits b. Lack of Motivation c. Lack of Personal Benefits and d. Poor Working. So to reduce attrition industries should create some opportunities for the growth of their employees within the organization by adopting new Innovative Technologies and Effective training programs. The attrition depends not only on Employee related factors but also on organization related factors. Researchers also emphasize that there is 'one fit size for all' solution and thus every organization needs to do proper diagnosis to unravel employee turnover issue in the organization and plan retention strategy accordingly. Although most of the studies interpret that most of the employees are dissatisfied with career advancement plans, nature of job and conditions of service. And some of the employees were dissatisfied with the training \& development part and working environment of the organization. Intrinsic factors are equally and sometimes more important than extrinsic factors while controlling attrition (Anantha A, 2013). It seems that Global recession and attrition, attrition and women labor force will be topics for future research. A vacant place of a skill labor may be filled by another new worker but production falls due to their skill difference. On the other hand, five or six semi-skilled or unskilled labor may be turnover but those empty places can be filled by one or two skilled labors (Swarnalatha C, Prasanna.T.S, 2013). It is therefore, crucial to maintain a constant workforce particularly for the skilled ones in an organization to reduce turnover for the betterment of the organization. One more important study realizes one way 
to reduce attrition by providing career advancement opportunities is critical for retention. High-quality communicating is valuable for company policy. It has been found a worthy effort to investigate the factors that cause or bring about employee turnover. But there is no significant differences were found in the reasons given for termination by males and females (Negi G, 2013).

Another interesting study revealed an inverse relationship between organizational commitment and turnover for employees employed more than one year, but on contrary a study indicates that this relationship was stronger for employees in their early career stages than those in later career stages (Adhikari \& Atanu, 2009) Companies should have a transparent functioning system so that every employee can know what he is expected to do in the organization. The changes of job by resources resulting into the attrition of human resources impacts significantly on the company's growth, financial planning and productivity. To sum up, there are results to confirm that the Performance of an organization is positively and significantly associated with employee turnover, workload, work stress, salary, and family to work conflict, because in our environment most of the workers are not satisfied with their jobs and most of them are ready to quit their present jobs once they find relatively better job (Dorance J\& Batty, 2014).

\section{Research Methodology}

\section{Hypothesis}

A hypothesis is a proposed explanation for a phenomenon. For this study following hypothesis can be drawn:

HO: There is no association between type of job (Engineers and non-engineers) and factors of attrition (Salary, Boss and Stress in organization) among the employees of manufacturing industry.

$\mathrm{H} 1$ : There is a strong association between type of job (Engineers and non-engineers) and factors of attrition (Salary, Boss and Stress in organization) among the employees of manufacturing industry.

\section{Research Design}

A research design is a systematic and detailed outline of how an investigation about scientific problem will take place. It is the overall strategy that we choose to integrate different components of study in logical way. It is the blue print of the collection, measurement and analysis of data.

\section{Descriptive research}

The research design used for conducting this research is Descriptive. In order to describe a specific behavior as it occurs in the environment. As in this research we are trying to gather descriptive information about a specific behavior i.e. attrition and its rate in manufacturing sector.

\section{Population and Sample}

Population is the total of all individuals who have certain characteristics and are of interest a researcher. It is generally a large collection of individuals or objects that is the main focus of a scientific problem. In this study population is comprised of all employees (engineers and non-engineers) working in private manufacturing in Delhi/ NCR.

Sample is a group of people, objects, or items that are taken from a larger population for measurement. The sample should be representative of the population to ensure that we can generalize the findings from the research sample to the population as a whole. In this study sample of size 75 
employees (63-engineers, 12-non engineers) was taken from one of the leading private manufacturing industry of Delhi/NCR.

\section{Sampling Method}

Sampling method refers to technique to choose a sample out of the population. In this study Convenience sampling method is used, due to scarcity of time and resources and also for the ease of accessibility. Total sample size is 1000 employees.

\section{Methods of collecting data}

Data for this study is comprised of following two data types:

- Primary data: Primary data are those data which are collected by the investigator himself/herself during the course of a research. In this study tool used for collecting primary data is Personal and telephonic interviews with the sample. A set of questions were asked from 75 employees (63-engineers, 12-non engineers) each either personally or over telephone to get rich knowledge about attrition rate in the company and reasons for the same. Heterogeneity in age, gender and level in hierarchy is maintained to better understand the reasons for exit.

- Secondary Data: Secondary data are the data which are being collected by someone else other than the investigator. Investigator only utilizes those data to meet out his/her specific purpose. In this study tool used for collecting secondary data were websites, journals, magazines, and newspapers.

\section{Limitation of the study}

Almost 1000 employees were interviewed before floating the questionnaire but only 75 of them agreed upon to respond. As most of them are either not comfortable or not open in sharing as the topic chosen is confidential. Although most of them are open in submitting verbal comments over the topic but they were hesitant in written or documented form. So the reposes were collected from 75 only. Moreover the study only focuses on three major factors of attrition thus leaving many more.

\section{Data processing and Analysis}

Table 1: Case Processing Summary

\begin{tabular}{|c|c|c|c|c|c|c|}
\hline & \multicolumn{6}{|c|}{ Cases } \\
\hline & \multicolumn{2}{|c|}{ Valid } & \multicolumn{2}{|c|}{ Missing } & \multicolumn{2}{|c|}{ Total } \\
\hline & $\mathrm{N}$ & Percent & $\mathrm{N}$ & Percent & $\mathrm{N}$ & Percent \\
\hline Category * Reason to exit & 75 & $100.0 \%$ & 0 & $.0 \%$ & 75 & $100.0 \%$ \\
\hline
\end{tabular}


Table 2: Category * Reason to exit Cross tabulation

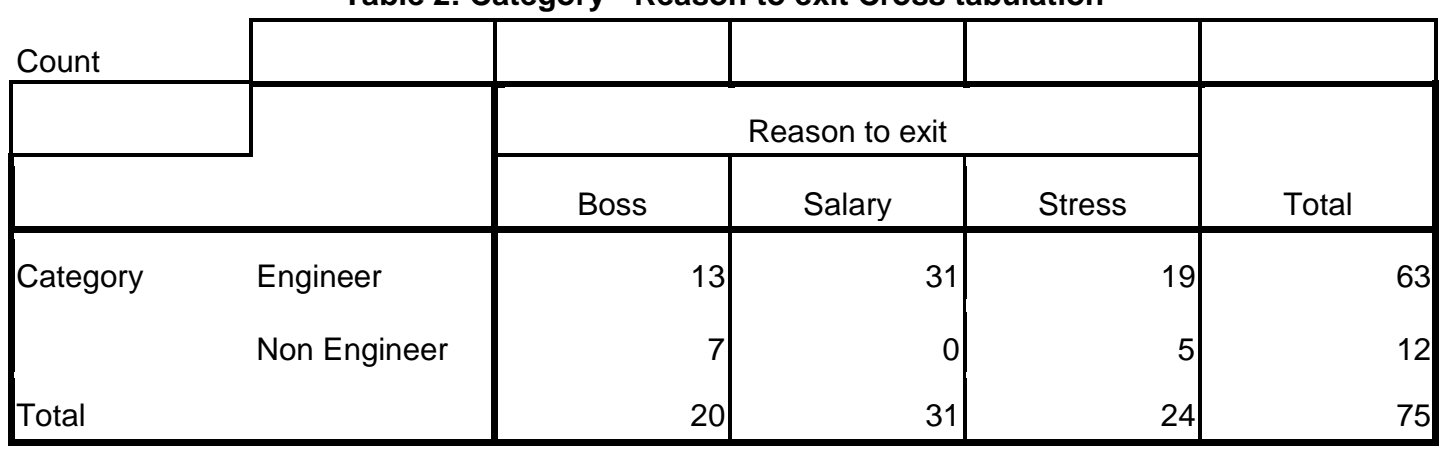

\section{Bar Chart}

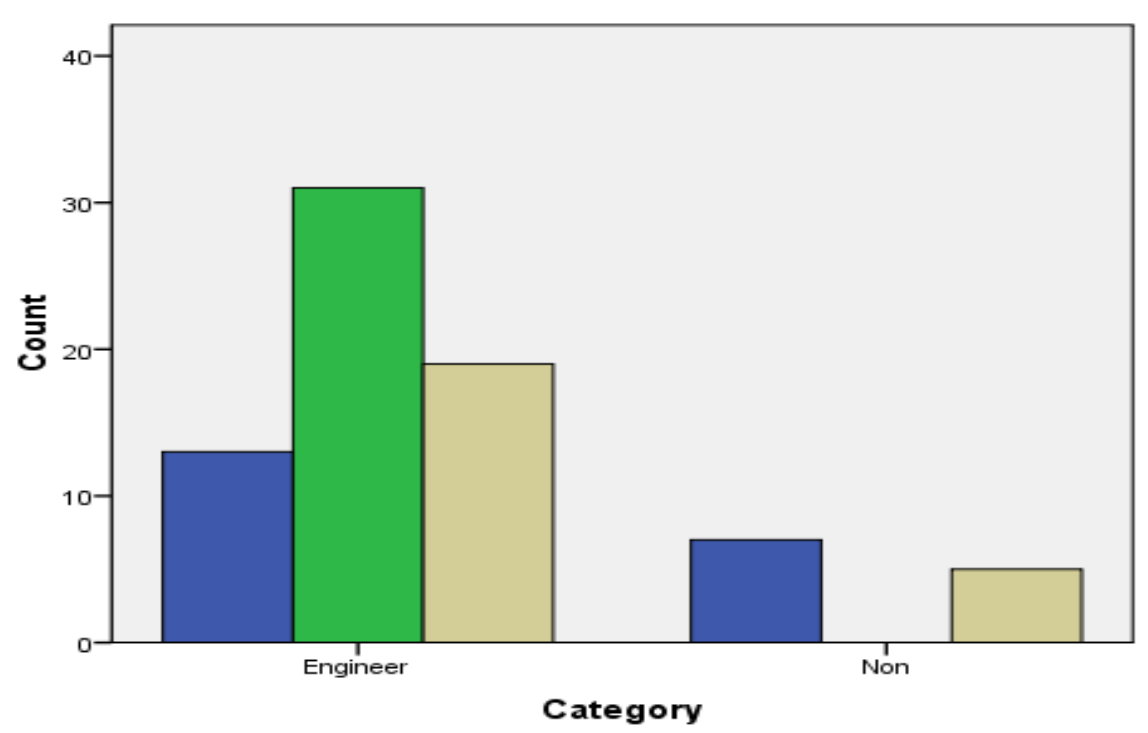

Fig 1: Response in Bar Chart

Data was collected from 75 respondents, out of which 63 were engineers and 12 were nonengineers.

From the above cross tabulation following interpretations were made:

- Out of 63 engineers , 13 said the Boss is the major reason for attrition, 31 said its salary and remaining 19 said due to stress employees leave organization.

- $\quad$ Out of 12 non-engineers responded, 7 founded Boss the major factor for attrition of employees and 5 said its stress. Whereas none of them opined for Salary as a reason for employees attrition rate. 
Table 3: Chi-Square Tests

\begin{tabular}{|l|r|r|r|}
\hline & Value & df & Asymp. Sig. (2-sided) \\
\hline Pearson Chi-Square & $11.694 \mathrm{a}$ & 2 & .003 \\
Likelihood Ratio & 15.489 & 2 & .000 \\
N of Valid Cases & 75 & & \\
\hline
\end{tabular}

a. 3 cells $(50.0 \%)$ have expected count less than 5 . The minimum expected count is 3.20 .

To determine whether there is a significant difference between the expected frequencies and the observed frequencies in one or more category, Chi-Square Test is applied. Chi-Square test also determines if the number of individuals or objects that fall in each category differ significantly from the number we would expect and also if this difference between expected and observed is due to sampling variation, or is a real difference. After applying Chi-Square test in data, out of 75 employees interviewed all the cases were found valid (engineers-63 and non-engineers-12).

To understand about factors boss, salary, stress (independent variables) affecting attrition rate (dependent variable) in manufacturing sector, t-test is used to see the difference between two means, $p$-value is observed. If $p$-value is less than 0.05 , it means that the difference between two values is significant. If $p$-value is more than 0.05 , difference is insignificant. "Sig" stands for significance level indicated by $p$-value.

As per responses given by engineers, $p$-value for independent variables i.e. boss, salary and stress over dependent variable i.e. attrition rate, is less than .05 . Hence attrition rate is dependent over boss, salary and stress for engineers. Null hypothesis are rejected and alternative hypothesis are accepted.

As per responses given by non-engineers, $p$-value for boss and stress are less than 0.05 but for salary it is more than 0.05 . Hence attrition rate is dependent over only boss and stress for nonengineers. Salary has no impact over attrition rate. For factors boss and stress, null hypothesis are rejected and alternative hypothesis are accepted. For salary factor, null hypothesis is accepted and alternative hypothesis is rejected.

\section{Major Findings}

- Major factors affecting attrition rate are boss, salary and stress in the organisation among employees.

- According to engineers out of boss, salary and stress factors, salary is the major factors affecting attrition rate.

- According to non-engineers attrition factors are boss and stress, out of which boss is the major factor. Whereas, salary has no impact over attrition rate, as per non-engineers.

- Factors of attrition are different for different types of job like supervisory, clerical, technical and non-technical. 


\section{Conclusion}

In this paper factors affecting attrition rate in manufacturing sector has been studied. A descriptive study has been done to find out those factors, where employees (63-engineers and 12-non engineers) from a manufacturing unit were interviewed either on personally with the set of structured questions. It can be concluded on the basis of the study that major factors affecting attrition rate are Boss, Salary and Stress. Mere sourcing, screening, offering and placing right talent, at right time and at place does not mean that organization will grow. Retaining right talent for right period of time will make a difference and assure growth and success of the organization. It is found on the basis of this study that today's manufacturing units are a bit casual on their approach for controlling attrition rate. Smooth and open communication channels should be there so as to improve employee-employer. Salary structure should be revised and proper hikes should be given and maintain.

Organization should have a serious approach towards employee work-life balance activities. Frequent initiatives should be taken so as decrease attrition rate. No matter how smart technology grows but the basic unit of any organization would always remain the same i.e. "PEOPLE". Thus a conscious effort on employee engagement and motivation must be taken to respond towards sustainable development of Manufacturing sector.

\section{References}

[1] Adhikari A, (2009). Factors Affecting Employee Attrition: A Multiple Regression Approach; The IUP Journal of Management Research,3(5),38-43.

[2] Anantha A, (2013), A Qualitative Study on Causes and Effects of Employee Turnover in the Private Sector in Malaysia; Journal of Scientific Research;16 (11),1532-1541

[3] Chang Cheng Ying, Cheng Wang-Wen,(2010).Structural Investigation of the Relationship between Working Satisfaction and Employee Turnover; The Journal of Human Resource and Adult Learning;6(1),93-102.

[4] Camara B, (2010). Causes of Employee Turnover; African Journal of Business Management; 4(19),41464158.

[5] Dwivedi T, (2013). Attrition in Indian Retail Industry: An Analysis of Organized Retail in North Eastern Uttar Pradesh; International Journal of Retailing \& Rural Business Perspectives;2(3),535-540.

[6] Swarnalatha C,Prasanna.T.S,(2013). Employee Turnover in Health Care Industry: A Concern for the Organization; The International Journal of Management;2(1),1-11.

[7] Dorance J, Batty (2014). A Study on Attrition - Turnover Intentions in Retail Industry. International Journal of Business Administration Research Review,1(3),2347-856X

[8] Dube Pradeepkant \&Dr. Verma Siddharth,(2015). Study of Attrition Trend and Influencing Factor in the Sectors of IT (Service) and Pharma (Manufacturing); International Journal of Social Science and Humanities Research ;3(1),388-393.

[9] Mishra S, Mishra D (2013). Review of Literature on Factors Influencing Attrition and Retention; International Journal of Organizational Behaviour \& Management Perspectives;2(3),435-444.

[10] Lavanya, L (2013). A Study on Employee Attrition and Retention in Manufacturing Indutries; BVIMSR's Journal of management Research;5(1), 192-203.

[11] Gupta Priya , Alamelupriya. R \& Sengupta Angan, (2013).Managing Attrition in Retail Sector:A Study of Firm in Bangalore; National Conference on Human Resource Management, NCHRM,Review of HRM Vol. 2,262-274.

[12] Jason H.Hammerberg,(2002).Reasons for Employee Turnover in a Full Priced Department Store; Human Resouce Management Review;17(5),374-377

[13] Kaur Savneet,(2013).Attrition in India - Causes \& Remedies; International Journal of Emerging Research in Management \&Technology;2(6),39-45.

[14] Md. Rahman Sahidur,Md.Uddin Kafil \& Akther Sharmin (2008).Investigating the Reasons of Employee Turnover in Bangladesh:A Factor Analysis;Journal of Business Administration;Volume 23,1-14. 
[15] Negi Gayatri,(2013). Employee Attrition : Inevitable Yet Manageable ;International Monthly Refereed Journal of Research In Management \& Technology; Vol 2,50-59.

[16] Raisinghani Manju,(2015). Managing Employee Attrition - an Empirical Study in Education Sector; Indian Journal of Applied Research;5(4),370-372.

[17] Shukhla Pradeep \& Sharma Manoj, (2012). Attrition Rate - The Role of HR Department; International Journal of Social Sciences \& Interdisciplinary Research;1(6),61-67.

[18] Shamsuzzoha AHM, Hasan Shumon Md. Rezaul,(2013).Employee Turnover-a Study of its Causes and Effects to Different Industries in Bangladesh;International Refereed Research Journal, Journal of Arts, Science \& Commerce.

[19] Tariq Muhammad Naeem, Ramzan Muhammad \& Riaz Aisha,(2013). The Impact of Employee Turnover on the Efficiency of the Organization; Interdisciplinary Journal of Contemporary Research in Business;4(9),700-711.

[20] Verma Rajesh, Aggarwal Aanchal,2012.A Study of Attrition Rate Among Sales Force of Life Insurance Companies in Delhi; Journal of Arts, Science \& Commerce, International Referred Research Journal; 3,4(1),90-99.

[21] Wambui Elizabath ,(2012).Perceived factors Influencing Employee Turnover in SDV Transami; The IUP Journal of Management Research;8(5). 